\title{
39 大学病院衛星医療情報ネットワークに対する手術部での対応
}

中谷 博, 中田精三, 鳥居 克, 河井敏博, 富田敏司, 梅下浩司, 上山博史, 高階雅紀, 越智隆弘 (大阪大手術部), 武田 裕 (大阪大医療情報部)

当手術部屽医学教育に使用するため, 昭和 36 年に RGB 万式のカラーテレビジョン・システムを尊入し た。昭和 50 年には一般放送用の NTSC 万式に更新し て外科系の教育に対応してきた。一力，NHK が開 発を進めていた高品位テレビジョン『ハイビジョン (HDTV)』についても，手術野の撮影を試み本学会で 報告した。更に，通信衛星による手術実況中継の経験 についても学会で報告してきた，平成 8 年12月 6 日に 8 大学間に抢いて, 大学病院衛星医療情報ネットワー $\eta$ (Medical Information Network by Communication Satellite for University Hospitals: MINCSUH) が開 局され，衛星通信地上局の一部として当手術部にも八 イビショョン送信装置が導入された。これは医療部門で は世界で初めてデジタル化されたハイビジョン画像情 報である。しかし，手術野の画像を通信衛星に乗せる にはセキュリティの問題がある. そのため画像は暗号 処理されて抢り，地上の制御回線を介して鍵信号を送
りエンューダで処理する.

当手術部では，全手術室に手術用 AV システムとし て NTSC 方式の 3 CCD カメラを導入している.今 回の大学病院を結ぶ衛星通信ネットワークは,このう らの 4 手術室にハイビジョンカメラの接続端子板を増 設して，AV 操作室のラックとは光ケーブルで接続し たものである。そのらち 1 手術室では手術用顕微鏡と 接続出来るよらに，天井の顥微鏡懸垂部の横に接続端 子を設けた。ハイビジョンカメラは移動式のスタンド にして，カメラコントロール及び VTR る移動式のラ ックに組み込んだものとした。、イビジョンカメラは 2/3 インチ， 130 万画素以上の CCD を 4 枚で撮像す る高精細画像である。また，既設の NTSC システム と接続でさるように NTSC 信号も同時に出力してい $\vec{b}$.

今回，本装置の導入経緯とその使用経験につき報告 する。

\section{0 漢方薬成分のラジカル捕捉能に関するシミュレーション 第 1 報}

山根禎子, 田代眞一 (昭和薬科大病態科学教室), 鈴木康生 (牛久愛和病院麻酔科), 山根 健 (国立熱海病院麻酔科), 山根健世 (社団法人山根医院), 高島征助（岡山大地域共同研究センター）

〔目的】漢方薬は多成分系であり経口的投与後消化管 内で代謝され効果を発現するが，その代謝経路は解明 されていない，幾つかの漢方薬の有效成分は，消化管 内の嫌気性腸内菌産生酵素により代謝され効果を発現 することが報告されているが漢方薬成分の代謝経路を 腸内細菌だけで説明することはできずラジカルの関与 も推定されている. 演者らは消化管内では様々な免疫 反応や生体防御反応が起こって扣り多くのラジカルが 発生しているという仮説に立ち，腸内での漢方薬成分 の代謝過程にも自然界で最も普遍的な酸素ラジカル・ ヒドロキシラジカルが関与していると推定した。 その シミュレーションの第 1 段階として高島らの作成した ラジカル発生装置を使って 5 種類の生薬成分にこれら のラジカルを単独に照射し，ラジカルとの反灿性につ いて検討した。

【方法】 5 種類の生薬の有効成分（由来，せンノサ イドA (大黄), ガルデノサイド (サンシシ), ジンセ ノサイド Rg 1 (人参), ジンセノサイド Rb 1 (人参),
ゲニポサイド（サンシシ）を各々単独で粉末のままガ ラス製容器に充填し, 減圧下で過酸化水素をグロ一放 電および柴外線照射することによって生成させた・O， ・ OHラジカルに接触させた。接触後の試料を蒸留水 に溶解して各々の水溶液の紫外部吸収スペクトルを測 定した。

〔結果】試料のラジカル反応性は紫外部吸収スペクト ルの極大吸収位置の吸光度の変化から算出した。セン ノサイドA，ガルデノサイド，ゲニポサイドは・O， ・OHラジカルにより吸光度が低下した。特にセン， サイド Aの・OHラジカルに接触させた際の紫外吸収 スペクトルの変化が最も顕著であったため, 赤外部吸 収スペクトル測定による検討も加えた。

[考察】今後, 高速液体クロマトグラフィーなどの手 段によりラジカルとの区応による試料の構造変化の検 捨を進め，また反応条件を弱アルカリで湿潤した消化 管内の条件に近づすよう検討を重ねる必要があると 考えられる。 